\title{
Business Ethics 101 for the Biotech Industry
}

\author{
Chris MacDonald \\ Department of Philosophy, Saint Mary's University, Halifax, Nova Scotia, Canada
}

\begin{abstract}
Biotechnology companies face ethical challenges of two distinct types: bioethical challenges faced on account of the nature of work in the life sciences, and corporate ethical challenges on account of their nature as commercial entities. The latter set of challenges has received almost no attention at all in the academic literature or media. This paper begins to remedy that lacuna, examining ethical issues that arise specifically on account of the status of biotech companies as commercial entities. The focus here is on three representative issues: product safety, corporate social responsibility, and corporate governance. It is argued that each of these issues poses particular ethical challenges for companies in the biotech sector. In the area of product safety, it is noted that biotech companies face particular challenges in determining what counts as a 'safe' product, given the contentious nature of what might count as a 'harm' in the biotech field. In the area of corporate social responsibility, the adoption of a 'stakeholder approach' and an attempt to manage the social consequences of products pose special challenges for biotech companies. This is due to the enormous range of groups and individuals claiming to have a stake in the doings of such companies, and the trenchant controversies over just what the social consequences of various biotechnologies might be. In the area of corporate governance, biotech companies need to seek out and follow best practices regarding the ways in which information, authority, and influence flow between a company's shareholders, managers, and Board of Directors, if they are to avoid duplicating the ethical and financial scandal that brought down ImClone. An important meta-issue, here - one that renders each of these corporate ethical challenges more vexing - is the difficulty of finding the appropriate benchmarks for ethical corporate behavior in a field as controversial, and as rapidly evolving, as biotechnology. Three programmatic suggestions can be made: Firstly, scholars and others interested in the ethical performance of the biotech sector must seek out and build opportunities for richer interdisciplinary collaboration. Secondly, companies within the biotech sector must seek out expertise and build capacity and competency in dealing with the corporate ethical issues that arise in their sector. Finally, companies in the biotech sector should explore the opportunities for collective problem solving afforded by the existence of local, national, and international industry associations such as the Biotechnology Industry Organization, BIOTECanada, and EuropaBio.
\end{abstract}

\section{Torn Between Two Worlds}

Companies in the biotechnology industry - like others in the life sciences - inhabit at once two different domains. On one hand, biotech companies are part of the healthcare system. The products and processes they develop often have as their aim the improvement of human health, the lessening of human pain, and the forestalling of human deaths. On the other hand, biotech companies are also commercial ventures. That is, they are legal entities that function by marshaling capital and human resources with the interrelated goals of (i) producing a product or service for which there is a market, and (ii) thereby producing a profit for their owners.

As inhabitants of two worlds, biotech companies face a doublebarreled array of ethical issues. One set of issues stems from the involvement of biotech companies in the life sciences and the healthcare system; the kinds of ethical issues that most readily spring to mind when the topic of ethics in biotechnology arises. These include the now-familiar front-page issues such as the moral status of human gametes and human fetuses, the permissibility of germ-line genetic modification, ${ }^{[1]}$ and whether cloning threatens 
what it means to be human. ${ }^{[2,3]}$ Also included under this general heading are further issues that are less likely to grab headlines, but that are none the less familiar to those with more than a passing knowledge of bioethics, including issues related to research on human subjects (consent, harm-benefit ratios, etc.), confidentiality, and the effects of genetic information on the lives of individuals and communities.

A second set of ethical issues is faced by biotech companies on account of their status as commercial ventures. Issues here include ethics in marketing and advertising, workers' rights (or labor relations more generally), environmental issues, issues related to corporate governance and investor relations, social accountability, and issues associated with carrying out business in foreign countries. Of course there is, in this list, nothing unique to the biotech industry: to an extent, biotech companies face the same ethical challenges as are faced by companies in any other sector of the economy. These issues comprise the field of business ethics - the study of ethical issues that arise in commercial ventures of all kinds. But for biotech companies, business ethics has a somewhat different flavor, or spin, owing to the uniqueness of the products these companies produce and the services they provide.

The topic under discussion here is this second set of ethical challenges, namely those that biotech companies face by virtue of their status as commercial enterprises. These challenges have historically proven particularly difficult for business ventures of all kinds. The scandals involving Enron, WorldCom, ImClone, and others are among the more recent 'sentinel events' that have focused attention on corporate ethics. But a quick look at headlines over the past few decades reminds us of the many major news stories that turned into business ethics case studies: the Ford Pinto, the Exxon Valdez, Dow Corning breast implants, and Union Carbide's disaster at Bhopal, to name a few. In each case, we see evidence of corporate executives and other employees choosing poorly when asked to choose between profit and ethics. But this tension - between obligations to shareholders and obligations to others - is not found only in these notorious cases. It is a tension endemic to the world of business. And the field of business ethics has historically had as its primary concerns: (i) the attempt to refute the claim, most famously voiced by Nobel Prize-winning economist Milton Friedman, that the only responsibility of busi- ness is to increase profits; $;^{[4]}$ and (ii) the attempt to explain ways in which businesses can honor the legitimate claims of shareholders and other investors, while at the same time paying due attention to the needs and rights of customers, employees, and neighboring communities.

For whatever reason, business ethics issues that arise in the field of biotechnology have received surprisingly little attention ${ }^{1}$. For as long as biotechnology has been a question of public concern, 'ethical issues in biotechnology' has been a topic 'owned' by bioethics (and, to a lesser extent, by environmental ethics). This has meant that a large number of ethical issues critical to the biotech industry, including product safety and corporate governance issues, have been effectively excluded from the agenda because they are largely beyond the ken of bioethics, as that field has traditionally been understood ${ }^{2}$.

At this point, individuals not familiar with the relevant academic literature may be perplexed. 'Bioethics'...'business ethics' ... what's the difference? It's all about ethics, isn't it? Fair enough. The distinction is, to a degree, artificial - a question of an arbitrary distinction drawn between two academic disciplines. Yet there is a significant degree of differentiation between the two fields. They are studied, for the most part, by different people. They are written about in different journals, and in different books. But biotech spans the two. And a number of the specific ethical issues that arise with regard to commercial biotechnology are in fact quite foreign to the sorts of considerations and frameworks that flow from the field of bioethics. So attending here to the corporate ethical issues that arise in biotech is part of an attempt to fill a gap in our practical and theoretical understanding of the ethical challenges faced in that industry.

\section{Corporate Ethical Issues}

In this section, three key issues of corporate ethics, namely product safety, corporate social responsibility, and corporate governance, are examined as they relate to biotechnology companies as commercial entities. In each case, the primary considerations found in the business ethics literature are outlined, and the notable differences, if any, in the form that the issue takes within the domain of biotechnology versus in other industries are discussed.

1 An informal search by the author indicates that the two leading journals in the field of business ethics, namely the Journal of Business Ethics and Business Ethics Quarterly, have between them published, over a 5 year period (1997 to August 2002), just seven articles related in some way to biotechnology.

2 For more on the complementarity of business ethics and bioethics, see Ells \& MacDonald. ${ }^{[5]}$ 


\section{1 Issue 1: Product Safety}

There is considerable literature on product safety, stretching back at least several decades. The old standard of caveat emptor ' let the buyer beware' - is now generally recognized as defunct. Corporations are recognized as having a duty of care with regard to both the obvious and the non-obvious safety-related aspects of their products. This duty is recognized as extending well beyond the requirements of law and regulation. ${ }^{[6]}$ Of course, it is widely recognized that no product is without risk: almost any product, if used wrongly, can result in injury. Because of this fact, "questions of safety are essentially questions of acceptable and known levels of risk". ${ }^{[7]}$ The operative question, then, is whether a given company has taken sufficient care to make sure that known risks associated with their products are made clear to consumers; and that their product is reasonably free of dangerous defects. The question of what counts as 'sufficient' care is, of course, a difficult one, but the concept at least provides a framework within which to evaluate the extent of a corporation's obligation.

More recently, a higher standard has emerged within the literature with regard to the responsibility of manufacturers for their products. Brenkert ${ }^{[8]}$ calls this the 'social products liability' doctrine. According to this doctrine, the manufacturer of a product may be held responsible for harms caused by that product, even if the product is in no way defective and even if the harm caused was not the result of some activity over which the manufacturer had direct control. The particular focus of Brenkert's own discussion is the putative responsibility of (at least some) gun manufacturers for (at least some) deaths caused by their products. Brenkert argues that, if such responsibility is plausible, it must be so because four conditions are met, namely: (i) significant harms have occurred; (ii) the actions of gun manufacturers (e.g. in their marketing strategies) contributed to those harms; (iii) those harms and their connection to the manufacturer's marketing practices were foreseeable; and (iv) there were alternative courses of action open to the industry and its member companies.

Brenkert makes two key points about the social products liability doctrine. The first is observational. Brenkert observes that, as a matter of fact, manufacturers in many industries are being held to this higher standard. The lesson for biotech companies is that, rightly or wrongly, the possibility exists that corporations in the biotech sector (to extend Brenkert's own argument) might be held responsible for the uses to which the technologies they develop are put. For example, it might someday come about that a pharmacogenomics firm is held responsible for a terrorist act made possible by its discovery of a genetic susceptibility, concentrated in a certain ethnic population, to a particular toxin. Brenkert's analysis suggests that the increasingly popular social products liability doctrine would permit a company to be held responsible for such a use of its discoveries, even if the company had no direct role in the terrorist acts in question.

Brenkert's second point is philosophical: he argues that there is indeed good ethical grounding for this emerging legal standard, that is, the idea that a manufacturer might be morally responsible for distant harms caused by uses of a product remote from the manufacturer's sphere of direct control. The implication is that the trend towards application of the stringent standard implied by the social products liability doctrine is not just happening: it is indeed happening for good reasons. Briefly, if companies produce a product that, in the current social context, may foreseeably contribute to undesirable outcomes, and if those companies make specific choices that contribute to, rather than mitigating, those harms, then it is at least prima facie reasonable that they be held collectively responsible for (some portion of) the resultant harms. And with the weight of good reason on its side, the social products liability doctrine can reasonably be expected to continue to gain ground. Of course, to say that there are good reasons to support this doctrine is not to conclude the debate. But the fact it is even advanced as plausible should make it clear that issues such as whether a pharmacogenomics corporation should be held responsible for distant, marginally foreseeable consequences of its discoveries are precisely the sort of business ethics issues with which biotech companies, and industry organizations, must increasingly develop competency.

Indeed, for the field of biotechnology, product safety is a special concern, both ethically and strategically. No company wants to face the public relations disaster that Monsanto encountered in relation to the marketing of genetically modified seeds and foods. ${ }^{[9]}$ This fear makes product safety management a crucial strategic consideration. Beyond pragmatic questions of good public relations, the ethics of product safety is an exceptionally challenging issue for biotech companies. Generally speaking, firms engaged in health research and the provision of healthrelated products and services are seen as being subject to very high ethical standards. Nowhere are ethical and legal standards for product safety more exacting than in fields related to human health.

To complicate things further, it may be difficult - indeed, impossible - to define what counts as a 'safe' product in the field of biotechnology. At least some of the dangers attributed to genetically modified foods by opponents of those products are dangers that are impossible to quantify and perhaps even difficult 
to define. Think, for example, of the claim that antibiotic-resistance genes (sometimes used as markers of genetic transformation) might spread from genetically modified plants to other organisms, ${ }^{[10]}$ or the claim that cloning threatens what it means to be human. ${ }^{[2]}$ The very measures according to which such risks should be judged are the subject of serious debate. This difficulty, combined with the growing significance of the social products liability doctrine, means that it may be exceedingly difficult for biotech companies in particular to seek out and follow appropriate standards and policies when it comes to product safety.

\subsection{Issue 2: Corporate Social Responsibility}

'Corporate social responsibility' (CSR) is a catch-all phrase often used to indicate the general sense in which corporations have obligations to the communities of which they are a part. CSR is a multi-faceted (and contested) concept. We will focus on two of its facets here.

First, attention to CSR can be taken to imply a willingness to attend to the needs of a wider range of stakeholders than has historically been the case for business corporations in general. According to adherents of what has come to be known in business circles as 'stakeholder theory', stakeholders are "those groups who can affect, or who are affected by, the activities of the firm". [11] Stakeholder theory (or, more generally, the stakeholder approach) seeks substantive ways to acknowledge that a wider range of parties are crucial to the success of the firm, and that many of these parties might in fact be owed serious, concrete, moral obligations.

The stakeholder approach - at least, those elements that suggest that attention to a broad range of stakeholders is not merely wise but morally mandatory - has become enormously popular, if somewhat contentious. Critics charge that the multiple lines of accountability implied by acknowledging a multiplicity of stakeholders reduces efficiency, ${ }^{[12]}$ and that indeed the very idea of stakeholders as morally significant undermines the morally-significant relationship between corporate executives and stockholders. ${ }^{[13]}$ Critics also note that the stakeholder approach is incapable of guiding necessary improvements in corporate governance. ${ }^{[14]}$ The financial catastrophes at Enron, WorldCom, and ImClone were all failures of corporate governance - that is, failures of the way organizations and institutional incentives were structured, resulting in failures of corporate behavior to align with corporate goals and policies. Such failures will surely not be made less likely, according to critics of stakeholder theory, if lines of accountability are multiplied. (Norman and Heath, unpublished manuscript). ${ }^{[15]}$
The adoption of a stakeholder management perspective, as part of a CSR strategy, may pose particular challenges for biotech companies. In particular, it can be very difficult to establish just who should be counted among a biotech company's stakeholders. Indeed, this is a problem for stakeholder theory in general. A central question in the literature relates to whose interests should have influence on managerial decisions, and how much? Biotech companies face special challenges in this regard, as their stock-intrade includes the very building blocks of all life - DNA, RNA, stem cells, etc. At least some of their activities have implications for (or are seen as having implications for) a very, very wide range of 'interested' parties indeed. So the range of potential stakeholders very quickly expands to include every human being on the planet, if not every living thing. Deciding how to pay appropriate attention to legitimate interests, without encumbering corporate decision-making and sliding into paralysis, constitutes a very serious - and under-explored - challenge for biotech companies.

A second relevant facet of CSR has to do with a corporation's willingness to attend to the social consequences of its products. In this regard, the socially responsible investment movement, for example, has supported a move away from investment in such socially problematic industries as the arms, tobacco, gambling, and alcohol industries. For many, the concern about these industries is not about individual instances of consumers using these products. The worry, rather, is that these industries are producing products that, when used by millions of customers, may have socially undesirable effects. That is, the social consequences of widespread smoking, drinking or gambling may include harms not captured by examining individual behavior.

Corporations can attend to the social consequences of their products and services in a number of ways. Some companies take action to mitigate the acknowledged negative social implications of their products. Some tobacco companies, for example, now produce anti-smoking literature aimed at teens. Other companies refuse entirely to sell certain products or services. Case in point: many American sporting-goods retailers now refuse to sell firearms. And hospitals, in many jurisdictions, refuse to permit fetal sex-selection, on the grounds that the associated devaluation of females (given that female fetuses are more often aborted in such scenarios) is socially pernicious.

Attending to the social consequences of their products poses special challenges for biotech companies, because the social consequences of many biotech products and services are the subject of serious debate. For example, many biotech companies, as well as many scientists, have already foresworn one significant biotechnology, namely reproductive cloning. For these companies and 
scientists, as well as for a very significant proportion of the general public, the social consequences (however ill defined) of cloning are simply unacceptable. So with regard to cloning, industry and the public are (generally) on the same page. But other topics engender greater disagreement. The social implications of advanced assisted reproductive technologies (and the special burden they represent for women), or of the development of drugs targeted to specific privileged (or under-privileged) ethnic groups, are as yet unclear. Biotech companies wishing to be socially responsible, in the sense of attending to the social implications of their products and services, face serious challenges, not the least of which is determining just what the social implications of those products and services are (or may one day be).

\subsection{Issue 3: Corporate Governance}

The Enron and Arthur Andersen scandals brought the question of corporate governance into the limelight. Indeed, there is reason to expect that corporate governance will be the key paradigm for both the theory and practice of business ethics for at least the next several years. Corporate governance systems are, roughly speaking, the systems by which corporations are directed and controlled. Such systems include the policies and procedures that determine how information, authority, and influence flow between a company's shareholders, managers and Board of Directors. From the point of view of business ethics, governance is about who has the right to determine the appropriate courses of action for a corporation, and how that right gets translated into actual corporate behavior.

The biotechnology industry had its own high-profile brush with governance issues in the ImClone scandal. In October 2002, Samuel Waksal, founder and former CEO of ImClone Systems, pleaded guilty to criminal charges including securities fraud, perjury, bank fraud, and obstruction of justice. In short, Waksal had used his knowledge of an impending negative decision by the US FDA concerning ImClone's new cancer drug, cetuximab, to profit in ways forbidden by American securities regulations. The criminal charges laid point to individual culpability; but the real lesson for the biotech industry lies in the larger failure of corporate governance evidenced at ImClone. ImClone's Board of Directors, for example, whose role it is to represent and protect the interest of shareholders, failed miserably at this task when they turned a blind eye to Waksal's forgery and fraud. Once they got wind of the trouble that was brewing, the members of the Board sold enough shares to devalue ImClone's publicly-traded stock, just prior to the FDA's critical decision.
But the ImClone scandal was, in a sense, relatively minor; the costs to the public were 'merely' financial. But in the field of biotech, it's easy to imagine failures in governance with much more worrisome consequences, both for public safety and for the long-term reputation of the industry. Imagine, for example, a CEO of a biotech company engaged in the development of a new form of gene therapy, deciding to slant (or even falsify) data submitted to the relevant regulatory bodies. Imagine the Board knowing about this, and failing to rein in the rogue CEO, because members of the Board stand to profit from the short-term inflation of stock prices that would follow regulatory approval of the new therapy. Such a failure of corporate governance - rooted at least partly in faulty structuring of Board compensation - could have disastrous consequences both for patients and for stockholders.

Governance issues won't necessarily look dramatically different at biotech companies than at other companies. Two factors do warrant mention, however. First, many biotech companies are founded by scientist-entrepreneurs, many of whom won't have a detailed knowledge of management, let alone knowledge of stateof-the-art corporate governance structures, or the niceties of securities regulations. Secondly, the rate of change and the financial pressures of the biotech industry may encourage companies to play fast-and-loose with the rules. The short timeline often experienced from making a scientific discovery (perhaps at a university lab), forming a spin-off commercial enterprise, acquiring venture capital and making an Initial Public Offering, through to product development and commercialization, may simply be inconsistent with careful planning of governance structures. Slowing down long enough to find clarity about how best to direct the business of the company in the interests of stockholders (with suitable attention to the public good) may not be easy, but it is nonetheless crucial.

\section{Searching for Guidance: Ethics Benchmarking in the Biotech Industry}

Perhaps the most general way of describing the ethical challenge faced by companies in the biotech industry is by reference to the notion of benchmarking.

Benchmarking is the process of determining who within a given field is the very best, who sets the standard for excellent performance, and what that standard is. As it pertains to corporate ethics, benchmarking involves assessing hot key issues and surveying one's industry and relevant stakeholders to determine which companies are 'getting it right'. In this regard, biotech companies face a very serious ethical challenge. It is difficult, if not impossible, to 
determine within the field of biotech who sets the standard and what that standard is. The simple reason is that within biotech, standards of ethical performance are even more hotly contested than they are in other, more traditional industries.

Where can biotech firms look to for the relevant benchmarks? It seems trite at this juncture to point out that the science of biotechnology is advancing so rapidly that legal and ethical frameworks can scarcely keep pace. None the less, it is of course not entirely true to say that corporate decision-making takes place in a vacuum; indeed, there exists a fairly wide range of national and international guidelines that, in some sense or another, govern the biotech industry. Noteworthy examples here include international treaties such as the International Treaty on Plant Genetic Resources for Food and Agriculture, ${ }^{[16]}$ the Convention on Biological Diversity, ${ }^{[17]}$ and the World Trade Organization (WTO) Agreement on Trade-Related Aspects of Intellectual Property. ${ }^{[18]} \mathrm{Bi}-$ otech companies are also subject to various bits of national legislation. For example, Canadian biotech companies are subject to such pieces of Canadian legislation as the Patent Act, ${ }^{[19]}$ the Plant Breeders' Rights Act, ${ }^{[20]}$ and, provided it passes the necessary parliamentary hurdles, the new Act Respecting Assisted Human Reproduction (expected to be made law sometime during 2004). ${ }^{[21]}$ Finally, biotech companies may also be subject to (or perhaps, more accurately, guided by) the industry's own guidelines, as embodied in the Statement of Ethical Principles adopted by the Biotechnology Industry Organization (BIO) ${ }^{[22]}$ and BIOTECanada, ${ }^{[23]}$ and EuropaBio's Statement of Ethical Values. ${ }^{[24]}$

So, on the face of it, it would be false to say that the biotech industry lacks guidance. But still, it seems fair to suggest that there is not much ethical certainty in this area. International conventions on biotechnology are open to - indeed, they are in need of national and local interpretation and contextualization. National laws such as Canada's Patent Act are notorious for the awkwardness with which their terms apply to the living things that make up the biotech industry's stock in trade. And although the industry is to be applauded for having taken steps to develop its own guidelines, those guidelines are far from providing precise roadmaps through treacherous moral terrain. So extant industry-wide ethics guidelines, while a step in the right direction, will not always provide adequate direction. Given the fact that public opinion regarding the moral standing of various biotechnologies is mercurial and often ill-informed, and that the opinion of experts in law and ethics is similarly deeply divided, one can be forgiven for wondering where even well-intentioned biotech companies can look to for reliable guidance.

\section{Conclusion}

The goal of the present paper has been to introduce readers to a set of ethical challenges that biotech companies face not by virtue of their status as life-science enterprises, but by virtue of their status as commercial enterprises. No claim has been made that biotech companies are fully unique in this regard; the claim has merely been that, to date, too much discussion about ethical issues in biotechnology has been carried out with disregard for the fact that biotech research, development, and commercialization is often done in a corporate context. To the extent to which the corporate context has been noted in the literature on biotech ethics, such attention has generally been limited to cynicism about corporate motives. This is not surprising: in the decade of Enron, WorldCom, and ImClone, scholars, journalists, and indeed the general public may be forgiven for a degree of skepticism. But skepticism is where enquiry begins; in itself, it does not solve hard problems.

The first three quarters of a decade of intensive public attention to the world of biotechnology (beginning roughly with the birth of Dolly, the world's first cloned mammal, in 1996) was dominated by discussion of bioethical issues. Is cloning 'unnatural'? Is germline gene therapy too dangerous? When does human life begin? Is individual consent to genetic testing for familial diseases sufficient? The next decade will see - indeed, must see - increased attention to corporate ethics in the world of biotech. As biotech moves from a realm of speculative science to a realm of serious commercial enterprises, ethical reflection on that realm must shift as well. In a world of commercial biotechnology, questions of corporate ethics, including questions related to product safety, CSR, and corporate governance, will increasingly come to dominate the field of biotech ethics.

Once we are collectively aware of this second set of ethical challenges, and the vast body of related literature made available by scholars in the field of business ethics, what way forward is available? I conclude with three brief and programmatic suggestions.

Firstly, scholars and others interested in the ethical performance of the biotech sector must seek out and build opportunities for richer interdisciplinary collaboration. Biotech is already a richly interdisciplinary field; biotech ethics is even more so. Yet the argument here suggests that including scholars from the field of business ethics will return greater dividends still.

Secondly, companies within the biotech sector must seek out expertise and build capacity and competency in dealing with the corporate ethical issues that arise in their world. Enhancing capa- 
city in this regard will not ensure that a company does not become the next ImClone. It may help, however, to ensure that when the light of public scrutiny is cast its way, the reasons that a company is able to give for the decisions it has made will be better, richer, and more well thought-out ones.

Finally, companies in the biotech sector should explore the opportunities for collective problem solving afforded by the existence of local and national industry associations such as BIO, BIOTECanada, and EuropaBio. Such organizations may well have the resources, the motivation, and the public legitimacy to develop standards and corporate 'best practices' in ways beyond what is possible for individual companies. To date, such organizations have done too little. But in a competitive domain beset by ethical uncertainty, they seem as good a hope as any for finding creative, shared solutions that are both mindful of the economic realities, and at the same time socially responsible.

\section{Acknowledgements}

This research was supported in part by a grant from the Nova Scotia Health Research Foundation, and a New Faculty grant from Saint Mary's University. The views expressed here are those of the author, and not necessarily those of these organizations. Thanks to Bryn Williams-Jones, Wayne Norman and Rahul Dhanda for helpful comments. Special thanks also to three supportive anonymous reviewers for this journal, for their many thoughtful suggestions.

\section{References}

1. McKibben B. Enough: staying human in an engineered age. New York: Times Books, 2003

2. Baird PA. Should human cloning be permitted? Ann R Col Physicians Surg Can 2000; 33 (4): 235-7

3. MacDonald C. Yes, human cloning should be permitted. Annals R Coll Physicians Surg Can 2000; 33 (7): 437-8

4. Friedman M. The social responsibility of business is to increase its profits. N Y Times Mag 1970 Sep 13: 122-126

5. Ells C, MacDonald C. Implications of organizational ethics to healthcare. Healthc Manage Forum 2002 Fall; 15 (3): 32-8

6. Shaw WH, Vincent B. Moral issues in business. 8th ed. Belmont (CA): Wadsworth, 2001
7. Velasquez MG. Business ethics: concepts and cases. 5th ed. Upper Saddle River (NJ): Prentice Hall, 2002

8. Brenkert GG. Social products liability: the case of firearms manufacturers. Bus Ethics Q 2000; 10 (1): 21-32

9. Dhanda RK. Guiding Icarus: merging bioethics with corporate interests. New York: Wiley-Liss, 2002

10. Health risks of genetically modified foods [editorial]. Lancet 1999 May 29; 353 (9167): 1811

11. Freeman RE. Strategic management: a stakeholder approach. Boston (MA): Pitman Press 1984

12. Beausang F. Democratising global governance: the challenges of the world social forum [discussion paper no. 59]. Paris: Unesco/MOST, 2002. Available from URL: http://www.unesco.org/most/dsp59_en.pdf [Accessed 2004 Jan 15]

13. Marcoux AM. Business ethics gone wrong: CATO policy report. Washington, DC: CATO Institute, 2000 Jul 24; 22 (3): 10-12

14. Sternberg E. Corporate governance: accountability in the marketplace. London: Institute of Economic Affairs, 1998

15. Norman W, Heath J. Stakeholder theory: governance and public management: what can the history of state-run enterprises teach us in the post-Enron era? University of Montreal (unpublished manuscript)

16. International Treaty on Plant Genetic Resources for Food and Agriculture[online]. Available from URL: http://www.fao.org/ag/cgrfa/itpgr.htm [Accessed 2004 Feb 11]

17. Convention on Biological Diversity [online]. Available from URL: http://www.biodiv.org/conention/articles.asp [Accessed 2004 Feb 11]

18. Agreement on Trade-Related Aspects of Intellectual Property [online]. Available from URL: http://www.wto.org/english/tratop_e/trips_e.htm [Accessed 2004 Feb 11]

19. Patent Act. R.S.C. 1985 , c. P-4

20. Plant Breeders' Rights Act. R.S.C. 1990, c. 20

21. Respecting Assisted Human Reproduction [online]. Available from URL: http:// www.parl.gc.ca/PDF/37/2/parlbus/chambus/house/bills/government/ C-13_3.pdf [Accessed 2004 Feb 11]

22. Biotechnology Industry Organization. Bioethics statement of principles [online]. Available from URL: http://www.bio.org/bioethics/principles.asp [Accessed 2004 Jan 15]

23. BIOTECanada. About BIOTECanada -ethics [online]. Available from URL: http:// www.biotech.ca/EN/ethics.html [Accessed 2004 Jan 15]

24. EuropaBio. Ethical values [online]. Available from URL: http://www.europabio.org/pages/ev/ev_english.asp [Accessed 2004 Jan 15]

Correspondence and offprints: Dr Chris MacDonald, Department of Philosophy, Saint Mary's University, Halifax, NS, B3H 3C3, Canada.

E-mail: chrismac@ethicsweb.ca 
Copyright of BioDrugs is the property of ADI BV and its content may not be copied or emailed to multiple sites or posted to a listserv without the copyright holder's express written permission. However, users may print, download, or email articles for individual use. 